Disease Focus

Editor's Note: Disease Focus articles provide brief overviews of a neural disease or syndrome, emphasizing potential links to basic neural mechanisms. They are presented in the hope of helping researchers identify clinical implications of their research. For more information, see http://www.jneurosci.org/misc/ifa_minireviews.dtl.

\title{
The Role of the Trigeminal Sensory Nuclear Complex in the Pathophysiology of Craniocervical Dystonia
}

\author{
Lynley Bradnam ${ }^{1,3}$ and Christine Barry ${ }^{1,2}$ \\ ${ }^{1}$ Applied Brain Research Laboratory, Centre for Neuroscience, ${ }^{2}$ Department of Anatomy and Histology School of Medicine, and ${ }^{3}$ Effectiveness of Therapy \\ Group, Centre for Clinical Change and Healthcare Research, School of Medicine, Flinders University, Bedford Park 5042, South Australia, Australia
}

Isolated focal dystonia is a neurological disorder that manifests as repetitive involuntary spasms and/or aberrant postures of the affected body part. Craniocervical dystonia involves muscles of the eye, jaw, larynx, or neck. The pathophysiology is unclear, and effective therapies are limited. One mechanism for increased muscle activity in craniocervical dystonia is loss of inhibition involving the trigeminal sensory nuclear complex (TSNC). The TSNC is tightly integrated into functionally connected regions subserving sensorimotor control of the neck and face. It mediates both excitatory and inhibitory reflexes of the jaw, face, and neck. These reflexes are often aberrant in craniocervical dystonia, leading to our hypothesis that the TSNC may play a central role in these particular focal dystonias. In this review, we present a hypothetical extended brain network model that includes the TSNC in describing the pathophysiology of craniocervical dystonia. Our model suggests the TSNC may become hyperexcitable due to loss of tonic inhibition by functionally connected motor nuclei such as the motor cortex, basal ganglia, and cerebellum. Disordered sensory input from trigeminal nerve afferents, such as aberrant feedback from dystonic muscles, may continue to potentiate brainstem circuits subserving craniocervical muscle control. We suggest that potentiation of the TSNC may also contribute to disordered sensorimotor control of face and neck muscles via ascending and cortical descending projections. Better understanding of the role of the TSNC within the extended neural network contributing to the pathophysiology of craniocervical dystonia may facilitate the development of new therapies such as noninvasive brain stimulation.

\section{Introduction}

Primary focal dystonia is a poorly understood neurological disorder presenting as involuntary sustained or intermittent muscle contractions, which cause twisting and abnormal postures of a body part (Fahn, 1984; Albanese et al., 2013). Common forms of focal dystonia affecting muscles of the head and neck are blepharospasm (eyelid blinking or eye closure); and oromandibular, laryngeal, lingual, cranial, and cervical dystonia (Jinnah et al., 2013). Onset is usually at $\sim 40-60$ years of age, and as yet no one particular

Received Aug. 19, 2013; revised 0ct. 7, 2013; accepted 0ct. 11, 2013. We thank Dr Sebastian Doeltgen for insightful comments on earlier versions of the manuscript.

The authors declare no competing financial interests.

Correspondence should be addressed to Lynley Bradnam, GPO Box 2100, Adelaide 5001, SA, Australia. E-mail: Lynley.bradnam@flinders.edu.au. DOI:10.1523/JNEUROSCI.3544-13.2013

Copyright $\odot 2013$ the authors $\quad 0270-6474 / 13 / 3318358-10 \$ 15.00 / 0$ causative gene has been identified (Phukan et al., 2011; Lohmann and Klein, 2013). Primary focal dystonia affects $\sim 20$ persons per 100,000 population and is the third most common movement disorder worldwide (Steeves et al., 2012), although it is likely that this figure is underrepresentative as diagnosis is a recognized problem (Albanese et al., 2011). Dystonia is characterized by pain and disability that persists for life, limiting daily activities like driving and working. Psychiatric comorbidities such as compulsive behaviors and depression are common (Zurowski et al., 2013). There is good evidence that dystonia reduces quality of life both for people with the disorder and for their caregivers (Battaglia et al., 2006; Lim, 2007; Slawek et al., 2007; Pekmezovic et al., 2009; Zetterberg et al., 2009). Despite the high incidence, dystonia remains poorly understood, and treatment options are lim- ited. For craniocervical dystonia, injections of botulinum toxin are the most common treatment at present but are not effective or tolerated by all patients (Snaith and Wade, 2011; Batla et al., 2012). In this article, we review the evidence for a role of the trigeminal sensory nuclear complex (TSNC) within the wider distributed network of brain regions contributing to the pathophysiology of craniocervical dystonia. We illustrate the putative neural circuitry using hypothetical models. Finally, we suggest novel treatment interventions for craniocervical dystonia that indirectly target the TSNC.

Does the trigeminal sensory nuclear complex play a role in craniocervical dystonia?

Neurophysiological studies in people with dystonia have identified reduced inhibition in the CNS, in particular the sensori- 
motor cortex, basal ganglia, brainstem, spinal cord, and the cerebellum (Jinnah and Hess, 2006; Quartarone et al., 2009; Hallett, 2011; Neychev et al., 2011). Anatomical, neurophysiological, and clinical data also point to involvement of the TSNC in certain presentations of dystonia that affect facial and neck muscles. Neurons of the TSNC receive extensive convergent input from afferents supplying diverse structures of the head and neck involved in nociceptive and nonnociceptive signaling, and project in turn to the somatosensory cortex (Abrahams et al., 1979; Sessle et al., 1986; Bartsch and Goadsby, 2002, 2003; Mørch et al., 2007; Takeda et al., 2012). Moreover, the TSNC has extensive connections to primary motor cortex (M1) and brainstem motor regions, enabling it to indirectly modulate spinal motoneuron excitability via multiple descending pathways. Support for a role of the TSNC comes from clinical studies whereby trigeminal reflexes impacting on the control of cranial, facial and cervical muscles are aberrant in dystonia (Nakashima et al., 1989; Di Lazzaro et al., 1995), consistent with decreased inhibitory modulation (Akalin et al., 2013). Interestingly, inadvertent or deliberate stimulation of trigeminal afferents in the form of sensory tricks, facial or tongue piercings, or dental devices ameliorates dystonia symptoms for some people (Gómez-Wong et al., 1998; de Entrambasaguas et al., 2007; Sims et al., 2012). Interest in the brainstem and TSNC in the pathophysiology of dystonia peaked in the 1980s and 1990s, but the advent of techniques such as transcranial magnetic stimulation (TMS) was accompanied by a shift in research focus to the cortex (Quartarone et al., 2009). The current understanding is that the basal ganglia and cerebellum together contribute to the dystonia phenotype via a functionally integrated motor network (Jinnah and Hess, 2006; Neychev et al., 2008; Neychev et al., 2011). We propose that this model should also include the TSNC when considering the pathophysiology underling craniocervical dystonia.

\section{Organization and function of the trigeminal nerve}

The organization of the trigeminal nerve and its central components is summarized in Figure 1. The small motor component innervates the muscles of mastication. The large sensory component involves all three divisions of the trigeminal nerve and conveys afferent input from the skin and muscles of the face and jaw, temperoman-

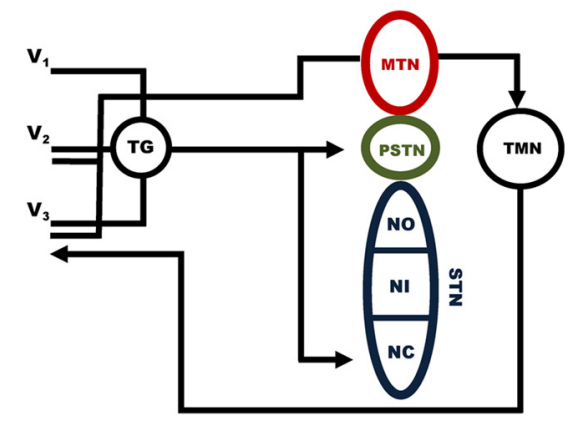

Figure 1. Schematic of the trigeminal nerve and the TSNC. Sensory inputs from the ophthalmic $\left(V_{1}\right)$, maxillary $\left(V_{2}\right)$, and mandibular $\left(V_{3}\right)$ divisions are conveyed via their cell bodies in the trigeminal ganglion (TG) to the principal sensory trigeminal nucleus (PSTN) and/or the spinal trigeminal nucleus (STN), which has three parts: the nucleus oralis (NO), nucleus interpolaris (NI), and nucleus caudalis (NC). The mesencephalic trigeminal nucleus (MTN) contains the cell bodies of primary afferent neurons with proprioceptive functions related to the teeth and muscles of mastication, and has direct projections to motor neurons of the trigeminal motor nucleus (TMN), enabling a rapid, monosynaptic reflex.

dibular joint (TMJ), cranial blood vessels, and dura to the CNS. The motor and sensory roots emerge adjacent to each other from the pons. The cell bodies of most trigeminal sensory fibers reside in trigeminal ganglia that are located in the floor of the middle cranial fossa.

\section{The trigeminal sensory nuclear complex}

The TSNC is elongated and extends from the midbrain to the upper cervical spinal cord (Fig. 1). It primarily receives input from trigeminal nerve afferents but also receives sensory input from structures not supplied by the trigeminal nerve, in particular the neck muscles (Sessle, 2000). The most superior part, the mesencephalic trigeminal nucleus, contains proprioceptive neurons with peripheral projections to periodontal receptors and muscle spindles in masticatory muscles. The principal sensory trigeminal nucleus receives input mainly from large-diameter fibers regarding discriminative sensation in the face and intraoral structures, along with proprioceptive input from the TMJ. The spinal trigeminal nucleus processes mechanical, thermal, and nociceptive input from the TMJ, facial, and cervical skin; oral and laryngeal mucosa; muscles of the neck, jaw, and tongue; the posterior dura, and cerebral arteries (Abrahams et al., 1979; Matsushita et al., 1981; Sessle et al., 1986; Sessle, 2000, 2002; Bartsch and Goadsby, 2002, 2003; Edvinsson, 2011). Collateral projections of trigeminal ganglion neurons have been traced to both the principal sensory nucleus and the spinal trigeminal nucleus ( $\mathrm{Li}$ et al.,
1992). Sensory inputs to the spinal trigeminal nucleus and the upper spinal cord segments overlap (Kerr, 1963), and wide dynamic range (WDR) neurons of the spinal trigeminal nucleus receive inputs from superficial and deep tissues, and from nociceptive and non-nociceptive afferents of trigeminal and upper cervical spinal nerves (Mørch et al., 2007; Takeda et al., 2012). This organization allows for afferent input from a wide range of head and neck structures to influence excitability of TSNC neurons, and for TSNC neurons to modulate activity in cranial and cervical muscles.

\section{Central projections of the TSNC}

The TSNC has extensive projections to other areas of the TSNC (Fig. 2), to motoneurons in the spinal cord and brainstem, to the cerebellum and basal ganglia, and via the thalamus to the motor cortex (Luo and Li, 1991; Sessle, 2000). Muscles of the face, eye, jaw, and neck are innervated by projections from the TSNC to motoneurons in the facial and trigeminal motor nuclei, to motoneurons located in the upper cervical spinal cord and to the superior colliculus (Sessle et al., 1986). From the mesencephalic nucleus proprioceptive neurons project to the trigeminal motor nucleus (Szentagothai, 1948), the reticular nuclei, the cerebellum (Billig et al., 1995) and as far caudally as the upper cervical cord (Matsushita et al., 1981; Wang and May, 2008). Neurons of the principal sensory nucleus ascend to the thalamus (Smith, 1975; Matsushita et al., 1981; Ro and Capra, 1994), the superior colliculus (Smith, 1975; Matsushita et al., 1981; Huerta et al., 1983; Ro and Capra, 1994; Pellegrini and Evinger, 1995), cerebellum (Somana et al., 1980), and the trigeminal (Smith, 1975) and facial motor nuclei (Erzurumlu and Killackey, 1979). Principal sensory nucleus neurons also project to the inferior olive (Xue et al., 2008) and the hypoglossal nucleus (Aldes and Boone, 1985). Neurons of the spinal trigeminal nucleus project caudally to mid and lower cervical motor neurons innervating neck muscles (Devoize et al., 2010), and, in cats, projections have been traced caudally as far as the T6 segment (Matsushita et al., 1981). Rostrally, the spinal trigeminal nucleus projects to the thalamus (Guy et al., 2005), the superior colliculus, and the cerebellum via the inferior olive (Huerta et al., 1983; Xue et al., 2008). This organization supports the TSNC as a key structure in a large neural network modulating activity in motoneurons supplying muscles of the neck and 


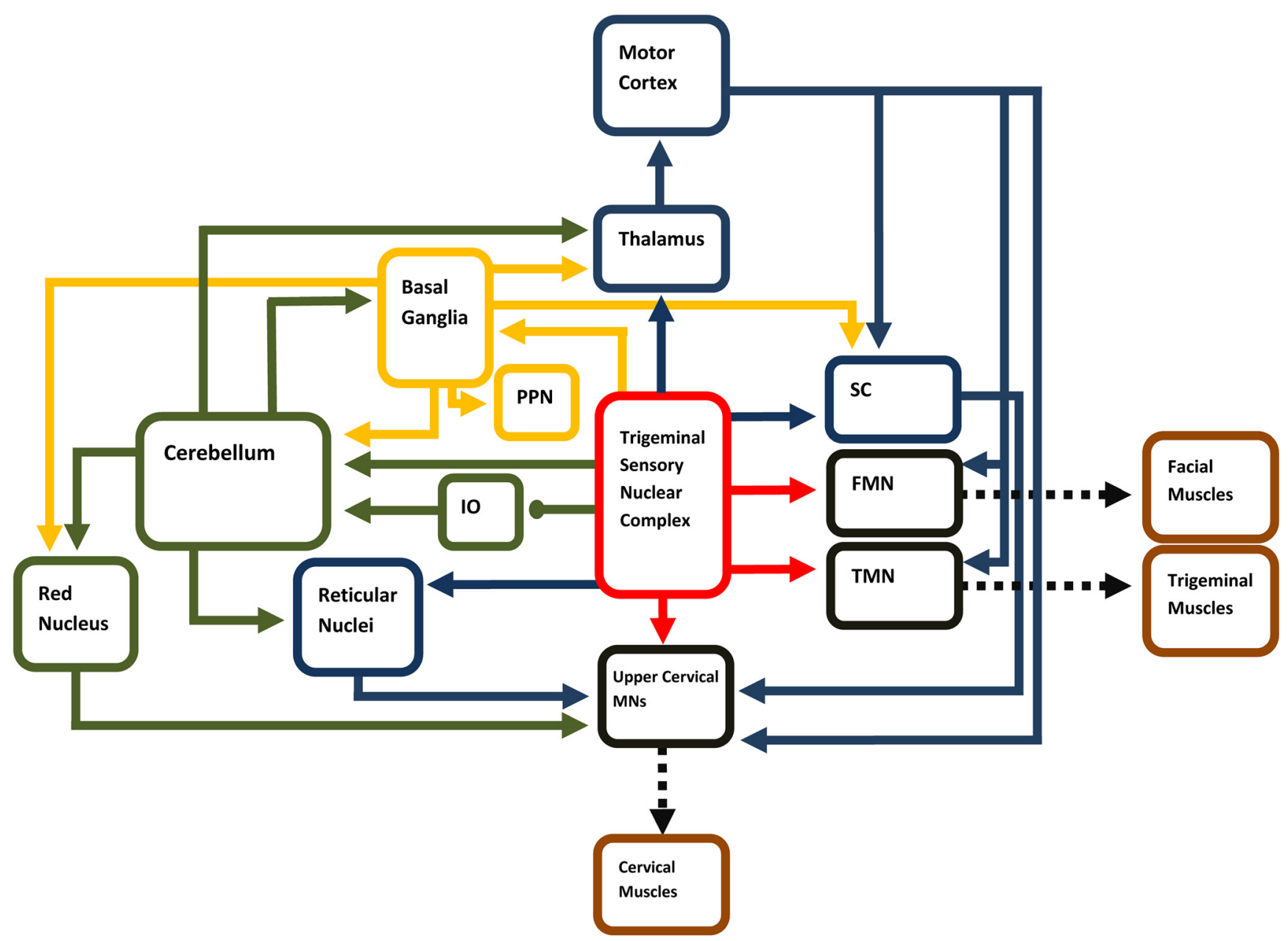

Figure 2. Schematic of an integrated network model including the TSNC in the pathophysiology of dystonia. The TSNC has direct projections (red) to motoneurons in the facial motor neurons (FMN), trigeminal motor neurons (TMN), and upper cervical motor neurons. Projections to muscles most commonly affected by dystonia are indicated by the hatched arrows. Ascending projections from the TSNC to the motor cortex via the thalamus, and to the superior colliculus (SC) and the reticular nuclei also modulate excitability via descending tracts to motor nuclei (blue). Excitatory inputs to the cerebellum and inhibitory inputs via the inferior olive (10; green) contribute to cortical and bulbar descending modulation of motoneurons innervating muscles affected by dystonia via cerebellar outputs to the red nucleus, reticular nuclei, basal ganglia, and motor cortex via the thalamus. TSNC projections to the basal ganglia (yellow) modulate excitability of descending projections to motoneurons by outputs to the motor cortex (via the thalamus), the superior colliculus, red nucleus, and the pedunculopontine nucleus (PPN). Connections from pedunculopontine nucleus to spinal cord are not shown in the simplified figure.

face, and, therefore, should be considered in network models for dystonia.

\section{Trigeminal reflexes}

Normal trigeminal nerve reflexes include the corneal and blink reflexes, jaw opening, jaw closing, and head retraction responses, and may be either excitatory or inhibitory in nature (Godaux and Desmedt, 1975; Ertekin et al., 1996, 2001). Trigeminal afferents contribute to relatively simple neural circuits in which the trigeminal nerve provides both the sensory and motor components of the reflex arc, for example, the jaw-closing reflex (Szentagothai, 1948; Nordstrom, 2007). Trigeminal afferents are also involved in more complex reflexes, such as the blink reflex, which relies on activation of the facial nerve (Valls-Sole, 2012), and trigemino-cervical reflexes, in which tri- geminal afferents modulate neck muscle activity via the spinal accessory nerve (Nakashima et al., 1989, 1992; Di Lazzaro et al., 1995, 2006).

The afferent limb of trigeminal reflexes can involve sensory A- $\beta$ fibers and lowthreshold non-noxious inputs (Cruccu et al., 1989; Komiyama et al., 2010) or noxious stimulation (Romaniello et al., 2000, 2003). Most trigeminal reflexes are consistently evoked at two latencies, indicative of separate neural pathways within the brainstem and upper cervical spinal cord (Di Lazzaro et al., 1996). Shortlatency reflex inhibition involves afferent fibers that terminate in the primary sensory nucleus, and impulses are relayed by interneurons to the ipsilateral and contralateral trigeminal, facial, or cervical motor nuclei (Milanov et al., 2001; Cruccu et al., 2005). Long-latency inhibition indicates complex polysynaptic pathways with fibers that project to the trigeminal spinal nucleus and higher-order neurons that ascend to the lateral reticular formation and terminate bilaterally on facial, trigeminal, or cervical motor nuclei (Cruccu et al., 2005).

Aberrant trigeminal reflexes are apparent in people who experience blepharospasm, and oromandibular, cranial, and cervical dystonia (Berardelli et al., 1985; Tolosa et al., 1988a, b; Nakashima et al., 1989; Alfonsi et al., 1992), with loss of reflex inhibition and increased reflex facilitation. In people with blepharospasm, and cranial and oromandibular dystonia, there is an increase in amplitude of both the early and late components of the blink reflex (Berardelli et al., 1985; Tolosa et al., 1988a, b; Schwingenschuh et al., 2011; Akalin et al., 2013). Paired stimulation of trigeminal af- 


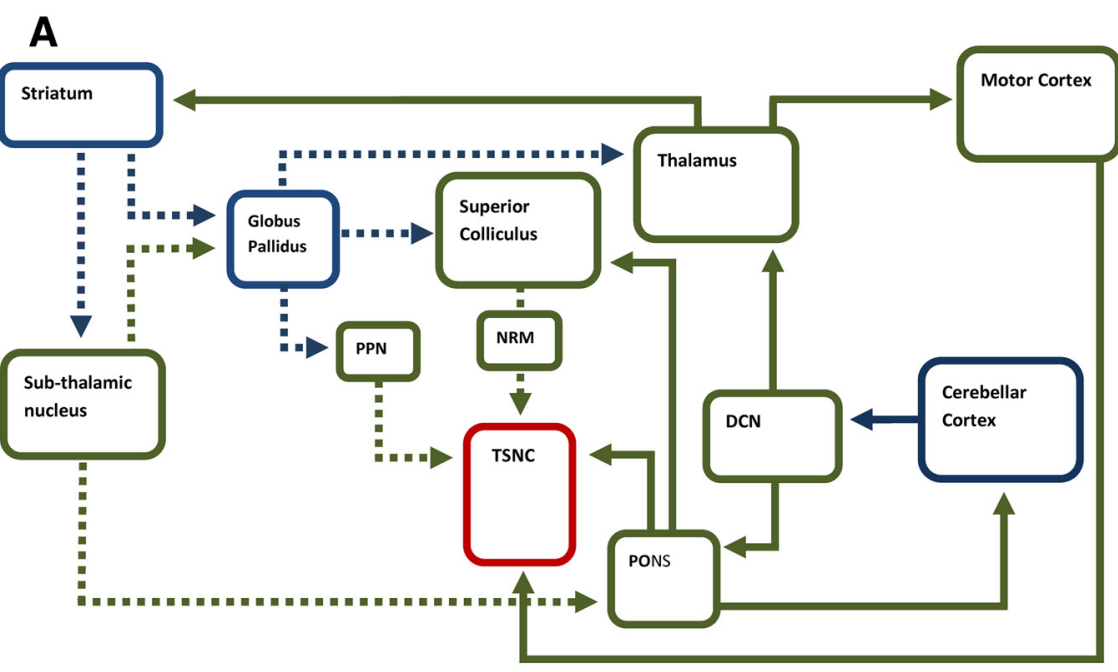

B

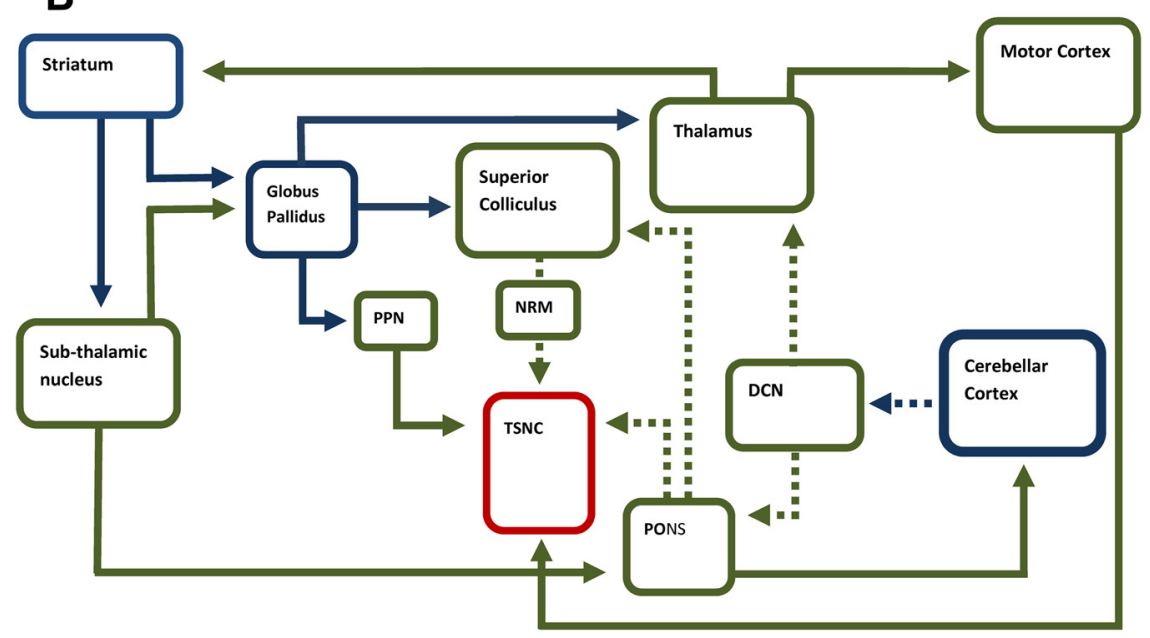

Figure 3. A simplified schematic showing disinhibition of the TSNC. Facilitatory projections are illustrated in green, inhibitory projections are illustrated in blue. The affected pathway is illustrated by the hatched lines. $\boldsymbol{A}$, Basal ganglia circuits can modulate the TSNC via projections from the subthalamic nucleus to globus pallidus (internus) that increase inhibitory modulation by the GPI over the superior colliculus and pedunculopontine nucleus, and increase excitability of the TSNC. The ascending pathways from basal ganglia to the motor cortex via the thalamus are shown. $\boldsymbol{B}$, The cerebellum projects to the TSNC via pontine nuclei and the superior colliculus, and via an ascending pathway to the motor cortex via the thalamus. Connections between the basal ganglia and cerebellum provide a common pathway for dysfunction in either or both to impact on TSNC excitability. From the cerebellar cortex, the deep cerebellar nuclei (DCN) project to striatum in the basal ganglia via the thalamus. The striatum in turn, projects to the cerebellar cortex by outputs from the subthalamic nucleus via the pons.

ferents in blepharospasm patients reveals hyperexcitability of trigeminal interneurons or blink reflex motoneurons (Tolosa et al., 1988a; Pauletti et al., 1993; Carella et al., 1994; Eekhof et al., 1996). Repetitive stimulation of trigeminal afferents in the same patient group enhances LTP-like blink reflex plasticity (Quartarone et al., 2006; Kranz et al., 2013). People with cervical dystonia have altered blink reflex recovery curves and aberrant masseter muscle reflexes (Tolosa et al., 1988a; Pauletti et al., 1993; Carella et al., 1994; Eekhof et al., 1996). There is also reduced reflex inhibition in the sternocleidomastoid muscle on trigeminal nerve stimulation in cervical dystonia patients compared with healthy controls (Nakashima et al., 1989; Carella et al., 1994). Together, these studies indicate dysfunction of trigeminal reflexes in people with dystonia, which may contribute to aberrant craniofacial and cervical muscle contractions.

\section{Adding the TSNC to an integrated network modal of dystonia}

It is now generally accepted that the pathophysiology underlying dystonia is described as an integrated network (Jinnah and Hess, 2006; Neychev et al., 2008, 2011). As the TSNC is a key part of the functional network subserving motor control of the head and neck, we propose that network models should be expanded to include the TSNC for craniocervical dystonia (Fig. 2). As we have outlined previously, the TSNC may contribute to the dystonia phenotype by direct activation of motoneurons innervating facial and neck muscles, and via indirect effects on interconnected motor regions, including the cerebellum, basal ganglia, reticular system, and motor cortex. Putative effects of TSNC disinhibition on motor output are summarized using four circuits in the schematic diagram in Figure 2. The most direct (red) involves short connections between the TSNC and motoneuron pools innervating dystonic muscles. The second (blue) involves projections from the TSNC to M1 via the thalamus to reticular neurons, giving rise to the reticulospinal descending pathway (Panneton et al., 2011), and to the superior colliculus, giving rise to the tectospinal pathway. The third (green) is the inferior olive-cerebellar loop. The TSNC projects to both inferior olive (Christian and Thompson, 2003; Gerwig et al., 2007) and cerebellum (Billig et al., 1995; Pellegrini and Evinger, 1997), and can modify the excitability of cerebellar projections to the thalamus and brainstem. In turn, output via corticospinal and corticobulbar projections, and tectospinal, rubrospinal, and reticulospinal pathways influence motoneuron pools innervating craniocervical muscles. Finally, TSNC outputs affect basal ganglia excitability (yellow). Basal ganglia project to M1 via the thalamus, to the cerebellum (Bostan and Strick, 2010; Bostan et al., 2010, 2013), pedunculopontine nucleus, superior colliculus, and red nucleus (Blood et al., 2012). The model proposes a potential role of the TSNC in an integrated functional neural network that may contribute to the underlying pathophysiology of craniocervical dystonia.

\section{A model of craniocervical dystonia involving loss of TSNC inhibition}

A critical question arising from the proposed model is what might lead to potentiation of the TSNC in people with craniocervical dystonia? Evidence indicates that the cerebellum and basal ganglia impose a level of tonic inhibition over neurons mediating trigeminal reflexes, and, if tonic inhibition is compromised, hyperexcitability in TSNC circuits may result (Fig. 3). This model may explain why people with blepharospasm demonstrate abnormal trigeminal nerve reflexes in circuits controlling unaffected as well as affected muscles (Quartarone et al., 2008). 
For example, people with spasmodic dysphonia and without dystonic symptoms affecting eye muscles exhibit enhanced blink reflex excitability (Cohen et al., 1989). Furthermore, blink reflexes, jaw closing, and trigemino-cervical reflexes are aberrant in people with either blepharospasm or cervical dystonia (Pauletti et al., 1993; Carella et al., 1994), consistent with a nonspecific reduction in inhibition over trigeminal reflex circuitry.

Dysfunctional plasticity in the basal ganglia may be critical in dystonia. Abnormal synaptic plasticity within the striatum has been observed in patients (Peterson et al., 2010), and rat models of dystonia also indicate striatal dysfunction (Song et al., 2013). The basal ganglia may contribute to dystonia via thalamocortical outputs that modulate descending control of affected muscles. However, magnetic resonance imaging in people with cervical dystonia demonstrates altered connections between the brainstem and basal ganglia (Blood et al., 2012). The basal ganglia may modulate the excitability of the brainstem TSNC via a pathway involving the superior colliculus or the pedunculopontine nucleus (Fig. 3A). Reduced dopamine in the substantia nigra causes an abnormally enhanced inhibitory output from the globus pallidus internus (GPI), supressing the superior colliculus and nucleus raphe magnus, and in turn disinhibiting the TSNC to potentiate trigeminal reflexes (Basso and Evinger, 1996; Basso et al., 1996). Alternately, reduction in substantia nigra and globus pallidus inhibitory modulation over the pedunculopontine nucleus may disinhibit the TSNC via cholinergic projections (Morcuende et al., 2002). Evidence supporting this model includes aberrant blink reflexes demonstrated by patients with Parkinson's disease, a known basal ganglia disorder (Penders and Delwaide, 1971; Kimura, 1973). Treatment with dopaminergic drugs normalizes blink reflexes in these patients (Battaglia et al., 2006). Inhibitory trigeminal reflexes in muscles of mastication are also reduced in people with Parkinson's disease (Nakashima et al., 1990), further linking the basal ganglia to altered trigeminal reflex activity. However, these latter findings do not elucidate whether the pathway is mediated by brainstem or cortical loops.

The cerebellum may also contribute to the pathophysiology underlying dystonia (Sadnicka et al., 2012). There is evidence that dysfunction of Purkinje cell firing induces dystonic motor behavior in rats (Raike et al., 2012; Todorov et al., 2012), and morphological degeneration of Pur- kinje neurons has been found postmortem in brains of people who suffered dystonia (Prudente et al., 2013). Pilot studies in our laboratory indicate that noninvasive stimulation to increase excitability of the cerebellum may transiently improve handwriting in people with focal hand and cervical dystonia (Bradnam et al., 2013). The cerebellum is likely to play a role in dystonia independent of the TSNC by indirect modulation of descending projections to cervical spinal cord motoneurons.

However, diminished inhibitory output from the cerebellum could also contribute to craniocervical dystonia by influencing excitability of the TSNC via indirect pontine projections or via modulation of the superior colliculus (Kawamura et al., 1982; Fig. 3B), and several studies demonstrating functional connections between the TSNC and cerebellum support this hypothesis. Projections arising from the mescencephalic nucleus to the cerebellum (Billig et al., 1995) are likely to enable processing of proprioceptive errors relayed from the temperomandibular joint and jaw-closing muscles. Trigeminal-cerebellar pathways would also enable adaptive modulation of the blink reflex in response to corneal stimulation and repeated orbicularis oculi muscle contractions, which do not occur following cerebellectomy (Pellegrini and Evinger, 1997). The latter findings are reinforced by a study in humans where proprioceptive error signaling following eyelid restraint was found to potentiate the blink reflex (Schicatano et al., 2002). Finally, a link between the cerebellum and the TSNC is strongly indicated by the finding that suppression of the cerebellum in healthy adults using noninvasive stimulation abolishes eye blink classical conditioning, which is known to rely on activity in the trigeminal-inferior olive-cerebellar loop (Hoffland et al., 2012). People with cervical dystonia develop the conditioned eye blink response less readily (Teo et al., 2009), but conditioned learning is enhanced following suppressive noninvasive cerebellar stimulation (Hoffland et al., 2013). Together, this evidence indicates that dysfunction between TSCN and cerebellum may contribute to the pathophysiology underlying craniocervical dystonia. Examination of the role of the cerebellum in modulating trigemino-cervical reflexes in both healthy adults and people with cervical dystonia is currently underway in our laboratory.

The basal ganglia and cerebellum are interconnected and influence each other's activity (Neychev et al., 2008; Bostan and
Strick, 2010; Bostan et al., 2010,2013; Neychev et al., 2011; Kranz et al., 2013), meaning that altered activity in both pathways could potentially disinhibit the TSNC. A primary dysfunction within the striatum (Song et al., 2013) could suppress cerebellar cortex output via projections from the subthalamic nucleus to brainstem pontine nuclei and the superior colliculus (Fig. 3A). Alternatively, a primary dysfunction in the cerebellar cortex may reduce inhibitory output from deep cerebellar nuclei and might result in excitation of the striatum via thalamostriatal projections. This in turn might enhance inhibition of globus pallidus by the striatum (Fig. 3B). Therefore, primary dysfunction in either region may impact activity and outputs of both regions.

Like the cerebellum, the superior colliculus could have direct involvement in cervical dystonia without influencing excitability of the TSNC. The superior colliculus is under basal ganglia, cerebellar, and descending cortical control, and modulates activity in cervical muscles directly via the tectospinal pathway (Fig. 2), as well innervating facial and neck muscles via the TSNC (Fig. 3). The primary motor cortex provides descending control over muscles innervated by trigeminal motor nuclei and direct projections to upper cervical motoneurons. A measure of cortical inhibition, the cortical silent period, is shortened in the orbicularis oculi and perioral muscle representations in people with cranial dystonia (Curra et al., 2000), but lengthened in dystonic and nondystonic sternocleidomastoid muscles in people with cervical dystonia (Odergren et al., 1997). These findings indicate that there may be aberrant descending control over trigeminal motor nuclei in craniocervical dystonia (Fig. 3). Another important consideration is that brainstem vestibular nuclei may contribute to abnormal muscle control in craniofacial dystonia; however, findings that vestibular reflexes are abnormal in cervical dystonia are mixed (Münchau and Bronstein, 2001; Münchau et al., 2001; Rosengren and Colebatch, 2010). Altered vestibular reflexes in cervical dystonia may be due to dystonic postures of the head, producing aberrant vestibular stimulation (Colebatch et al., 1995; Rosengren and Colebatch, 2010). Clearly, the underlying circuitry of craniocervical dystonia is complex and involves many cortical and subcortical nuclei. Our putative model is intended to highlight the importance of including the TSNC in the pathophysiology of craniocervical dystonia, while recognizing the impor- 
tance of the other neural components in the circuitry.

\section{Potentiation of the TSNC by afferent input}

If the TSNC plays a role in the pathogenesis of craniocervical dystonia, then maintenance of dystonia may result from the abnormal proprioceptive and nociceptive afferent feedback to the TSNC from dystonic muscles. This is supported by the many studies demonstrating altered trigeminal reflexes in chronic neck pain, and migraine and cervicogenic headache in a manner remarkably similar to dystonia (Schoenen et al., 1987; Nakashima and Takahashi, 1991; Bánk et al., 1992; de Tommaso et al., 2002; Milanov and Bogdanova, 2003; Nardone and Tezzon, 2003a, b; Proietti Cecchini et al., 2003; Nardone et al., 2008). In the rat, inflammatory arthritis of the TMJ leads to sensitization of WDR neurons in the spinal trigeminal nucleus and increases the responsiveness of these neurons to further afferent input (Takeda et al., 2012). In humans, infusion of hypertonic saline into a muscle of mastication reduces inhibitory trigeminal reflexes involving masticatory muscles (Wang et al., 1999) and neck muscles (Ge et al., 2004). These findings indicate that abnormal sensory inputs via trigeminal afferents can influence trigeminal reflex activity, which we propose could contribute to the maintenance of dystonia.

It is well recognized that nonnocioceptive and nocioceptive afferents converge onto WDR neurons within the TSNC and may contribute to WDR sensitization (Ellrich and Treede, 1998; Ellrich et al., 1998; Romaniello et al., 2000; Blood et al., 2012). In turn, sensitized WDR neurons respond to innocuous inputs as if they were nocioceptive (Takeda et al., 2012) further increasing trigeminal reflex excitability (Ertekin et al., 2001; Serrao et al., 2003; Blood et al., 2012). Trigeminal input may contribute to a self-perpetuating loop in dystonia, whereby TSNC disinhibition causes aberrant motor output, and the abnormal signaling by proprioceptors and nocioceptors promotes ongoing activation of sensitized WDR neurons. In summary, we propose that once the extended network subserving dystonia is potentiated, afferent feedback from dystonic muscles themselves may contribute to hyperactivity in TSNC neural circuits to maintain symptoms.

\section{Is the TSNC a potential}

therapeutic target?

If potentiation of the TSNC contributes to the expression of cranio-cervcial dystonia, the trigeminal nerve and sensory nuclear complex may provide a novel therapeutic target. Interventions that have been used to target the brain in cervical dystonia include deep brain stimulation (DBS) and noninvasive brain stimulation (NBS). Both approaches may have the potential to indirectly modify TSNC excitability by modulating brain nuclei with functional connections to trigeminal nuclei.

\section{Deep brain stimulation}

The DBS target that has shown good longterm efficacy in treatment cervical dystonia is the GPI (Hung et al., 2007; Jeong et al., 2009; Sadnicka et al., 2013; Witt et al., 2013). The GPI can influence the excitability of the TSNC via the pedunculopontine nuclei and the superior colliculus (Fig. 3). A recent study found that palladial stimulation improved the motor aspects of cervical dystonia but did not affect temporal sensory discrimination thresholds (Sadnicka et al., 2013). However, in this study temporal thresholds were only tested in the hand, and so it remains unclear whether TSNC excitability may have been impacted. Future studies investigating temporal sensory thresholds in the trigeminal nerve territory and trigeminal motor reflexes in patients undergoing DBS may elucidate the impact of altered basal ganglia function of TSNC excitability.

\section{Noninvasive brain stimulation}

Direct evidence that noninvasive stimulation of functionally connected brain regions can modulate the excitability of the TSNC is still lacking. However, NBS has been used as a trial treatment for focal dystonia by targeting several brain regions. These include M1 (Siebner et al., 1999; De Vito et al., 2009), the premotor cortex (Murase et al., 2005; Borich et al., 2009; Huang et al., 2010, 2012; Kimberley et al., 2013), and the cerebellum (Hoffland et al., 2013). An inhibitory repetitive TMS protocol applied to M1 suppressed the excitability of the blink reflex recovery curve in healthy adults (De Vito et al., 2009). This study has yet to be replicated in people with dystonia; however, it does indicate trigeminal reflexes may be modulated from supraspinal levels, possibly by corticobulbar projections from M1 to the TSNC. An inhibitory TMS protocol to M1 restored intracortical inhibition and pro- longed the cortical silent period, transiently improving writing performance in people with focal hand dystonia (Siebner et al., 1999). However, several studies using direct current stimulation to suppress M1 have shown little benefit for people with focal hand dystonia (Buttkus et al., 2010, 2011; Benninger et al., 2011). These negative results may stem from the fact that cathodal transcranial direct current stimulation does not induce normal inhibitory effects on M1 excitability in people with focal hand dystonia, possibly due to an impairment of synaptic homeostatic mechanisms (Quartarone et al., 2005). The potential for stimulating M1 to indirectly modulate TSNC excitability remains unclear, and studies assessing brainstem reflexes following M1 stimulation in people with craniocervical dystonia are needed.

Suppression of the premotor cortex with inhibitory TMS protocols has been found to normalize cortical silent periods and intracortical inhibition within M1 and is associated with improved handwriting in people with focal hand dystonia (Murase et al., 2005; Borich et al., 2009; Huang et al., 2010; Kimberley et al., 2013). In common with NBS to the motor cortex, studies investigating the effects of premotor cortex stimulation on brainstem reflex excitability in people with craniocervical dystonia are still lacking. Regarding the cerebellum, there is preliminary evidence that NBS to increase cerebellar excitability may normalize short afferent inhibition and cerebellar brain inhibition in M1, and may improve handwriting kinematics in people with focal hand and cervical dystonia (Bradnam et al., 2013). The most compelling evidence that NBS to the cerebellum can modulate excitability of the TSNC comes from a study whereby theta-burst stimulation to suppress cerebellum restored associative blink reflex conditioning in people with cervical dystonia (Hoffland et al., 2013). Studies investigating cerebellar modulation of sensory discrimination thresholds in the trigeminal afferent territory and other brainstem reflexes such as the trigemino-cervical reflex are needed. Experiments in larger cohorts of patients with craniocervical dystonia are warranted to assess the impact of NBS to regions of brain functionally connected to the TSNC by measuring effects on trigeminal brainstem reflexes and temporal discrimination thresholds assessed in the trigeminal afferent territory. If such studies support the theory that hyperexcitability of the TSNC contributes to the 
pathophysiology of craniocervical dystonia, they will support the potential for NBS to be an effective novel treatment intervention.

\section{Modulation of trigeminal afferent input}

Stimulation of trigeminal nerve afferents may provide an alternative therapeutic approach to NBS. The only treatment for primary focal dystonia that has demonstrated benefit in randomized clinical trials to date is botulinum toxin (Snaith and Wade, 2011; Batla et al., 2012). Botulinum toxin is an acetylcholine release inhibitor and so acts at the neuromuscular junction to reduce aberrant muscle contraction. By doing so, it also acts to normalize sensory input to the TSNC via trigeminal afferents. Whether normalization of afferent feedback by trigeminal afferents contributes to the benefits of botulinum toxin on dystonia is unclear. There is evidence for reorganization of hand motor cortex following botulinum toxin injections to neck muscles (Thickbroom et al., 2003; Kojovic et al., 2011), and some studies report the normalization of potentiated trigeminal reflexes following injections of the toxin into orbicularis occuli in blepharospasm (Quartarone et al., 2006), but others do not (Girlanda et al., 1996; Grandas et al., 1998). Furthermore, exercise therapy (with or without botulinum toxin) that may normalize afferent feedback from dystonic muscles also failed to demonstrate long-term improvement in motor control in people with cervical dystonia (Tassorelli et al., 2006; Zetterberg et al., 2008).

Trigeminal afferent input clearly contributes to the ability of some people to transiently suppress dystonia using a "geste antagoniste" (sensory trick), touching skin over the neck or face, and this maneuver is known to suppress activity in brainstem reflexes in people with blepharospasm (Gómez-Wong et al., 1998). Altered input from proprioceptive jaw afferents may also explain the transient success of mouthguards that alter jaw position in some people with cervical dystonia (Sims et al., 2012). Stimulation of afferent fibers with transcutaneous electrical nerve stimulation has also demonstrated benefit in patients with focal dystonia (Toglia and Izzo, 1985; FoleyNolan et al., 1990; Tinazzi et al., 2005). Afferent input provided by taping dystonic muscles was found to reduce pain, but not motor symptoms in cervical dystonia (Pelosin et al., 2013). Lowfrequency trigeminal nerve stimulation to reduce TSNC potentiation did not produce objective improvements in blepharospasm symptoms (Kranz et al., 2013). Further studies are required to understand whether modulating sensory inputs via trigeminal afferents has potential as a treatment intervention for craniocervical dystonia.

\section{Conclusion}

Trigeminal-mediated reflexes are deficient in craniocervical dystonia, indicating that the trigeminal sensory nuclear complex may play an important role, given its wide ranging projections to motor regions of the brain. Abundant anatomical evidence indicates that motor control of the head and neck relies on normal function of the TSNC reflex pathways, and therefore abnormal TSNC function may impact this control. We present an integrated network model that includes the TSNC in the pathogenesis of craniocervical dystonia. The proposed model explains how TSNC disinhibition can impact the excitability of motoneurons innervating facial and cervical muscles, both directly and indirectly via neural connections with the motor cortex, basal ganglia, and cerebellum. We propose a network involving the cerebellum, basal ganglia, superior colliculus, and motor cortex that contributes to potentiation within the TSNC via a reduction in inhibition, which generates a nonspecific increase in the excitability of trigeminal reflex circuits. Trigeminal afferent input from dystonic muscles may contribute to the maintenance of craniocervical dystonia. Noninvasive brain stimulation targeting neural inputs to the TSNC may provide a novel treatment option. Further research is warranted to determine whether noninvasive brain stimulation may normalize trigeminal reflexes and improve symptoms of craniocervical dystonia. Determining costeffective and efficacious treatments is extremely important as dystonia remains a poorly understood and managed neurological condition that severely impacts quality of life and well being for people who experience the disorder.

\section{References}

Abrahams VC, Anstee G, Richmond FJ, Rose PK (1979) Neck muscle and trigeminal input to the upper cervical cord and lower medulla of the cat. Can J Physiol Pharmacol 57:642-651. CrossRef Medline

Akalin MA, Kiziltan ME, Benbir G (2013) Blink reflex in patients with postparalytic facial syndrome and blepharospasm: trigeminal and auditory stimulation. Clin Neurophysiol 124: 120-125. CrossRef Medline
Albanese A, Asmus F, Bhatia KP, Elia AE, Elibol B, Filippini G, Gasser T, Krauss JK, Nardocci N, Newton A, Valls-Solé J (2011) EFNS guidelines on diagnosis and treatment of primary dystonias. Eur J Neurol 18:5-18. CrossRef Medline

Albanese A, Bhatia K, Bressman SB, Delong MR, Fahn S, Fung VS, Hallett M, Jankovic J, Jinnah HA, Klein C, Lang AE, Mink JW, Teller JK (2013) Phenomenology and classification of dystonia: a consensus update. Mov Disord 28: 863-873. CrossRef Medline

Aldes LD, Boone TB (1985) Organization of projections from the principal sensory trigeminal nucleus to the hypoglossal nucleus in the rat: an experimental light and electron microscopic study with axonal tracer techniques. Exp Brain Res 59:16-29. Medline

Alfonsi E, Pacchetti C, Lozza A, Conti R, Martignoni E, Bruggi P, Sandrini G, Arrigo A, Moglia A (1992) Electrophysiological study on jaw-opening reflex recorded from digastric muscle in Parkinson's disease and primary cranial dystonias. Funct Neurol 7:451-458. Medline

Bánk J, Bense E, Király C (1992) The blink reflex in migraine. Cephalalgia 12:289-292. CrossRef Medline

Bartsch T, Goadsby PJ (2002) Stimulation of the greater occipital nerve induces increased central excitability of dural afferent input. Brain 125: 1496-1509. CrossRef Medline

Bartsch T, Goadsby PJ (2003) Increased responses in trigeminocervical nociceptive neurons to cervical input after stimulation of the dura mater. Brain 126:1801-1813. CrossRef Medline

Basso MA, Evinger C (1996) An explanation for reflex blink hyperexcitability in Parkinson's disease. II. Nucleus raphe magnus. J Neurosci 16:7318-7330. Medline

Basso MA, Powers AS, Evinger C (1996) An explanation for reflex blink hyperexcitability in Parkinson's disease. I. Superior colliculus. J Neurosci 16:7308-7317. Medline

Batla A, Stamelou M, Bhatia KP (2012) Treatment of focal dystonia. Curr Treat Options Neurol 14:213-229. CrossRef Medline

Battaglia F, Ghilardi MF, Quartarone A, Bagnato S, Girlanda P, Hallett M (2006) Impaired longterm potentiation-like plasticity of the trigeminal blink reflex circuit in Parkinson's disease. Mov Disord 21:2230-2233. CrossRef Medline

Benninger DH, Lomarev M, Lopez G, Pal N, Luckenbaugh DA, Hallett M (2011) Transcranial direct current stimulation for the treatment of focal hand dystonia. Mov Disord 26:1698-1702. CrossRef Medline

Berardelli A, Rothwell JC, Day BL, Marsden CD (1985) Pathophysiology of blepharospasm and oromandibular dystonia. Brain 108:593608. CrossRef Medline

Billig I, Yatim N, Compoint C, Buisseret-Delmas C, Buisseret P (1995) Cerebellar afferences from the mesencephalic trigeminal nucleus in the rat. Neuroreport 6:2293-2296. CrossRef Medline

Blood AJ, Kuster JK, Woodman SC, Kirlic N, Makhlouf ML, Multhaupt-Buell TJ, Makris N, Parent M, Sudarsky LR, Sjalander G, Breiter H, Breiter HC, Sharma N (2012) Evidence for altered basal ganglia-brainstem connections in cervical dystonia. PLoS One 7:e31654. CrossRef Medline 
Borich M, Arora S, Kimberley TJ (2009) Lasting effects of repeated rTMS application in focal hand dystonia. Restor Neurol Neurosci 27: 55-65. CrossRef Medline

Bostan AC, Strick PL (2010) The cerebellum and basal ganglia are interconnected. Neuropsychol Rev 20:261-270. CrossRef Medline

Bostan AC, Dum RP, Strick PL (2010) The basal ganglia communicate with the cerebellum. Proc Natl Acad Sci U S A 107:8452-8456. CrossRef Medline

Bostan AC, Dum RP, Strick PL (2013) Cerebellar networks with the cerebral cortex and basal ganglia. Trends Cogn Sci 17:241-254. CrossRef Medline

Bradnam L, McDonnell M, Ridding M (2013) Non-invasive cerebellar stimulation in focal dystonia. Mov Disord 28:S10.

Buttkus F, Baur V, Jabusch HC, Paulus W, Nitsche MA, Altenmüller E (2010) Retraining and transcranial direct current stimulation in musician's dystonia-a case report. Mov Disord 25:1758-1760. CrossRef Medline

Buttkus F, Baur V, Jabusch HC, de la Cruz Gomez-Pellin M, Paulus W, Nitsche MA, Altenmüller E (2011) Single-session tDCSsupported retraining does not improve fine motor control in musician's dystonia. Restor Neurol Neurosci 29:85-90. CrossRef Medline

Carella F, Ciano C, Musicco M, Scaioli V (1994) Exteroceptive reflexes in dystonia: a study of the recovery cycle of the $\mathrm{R} 2$ component of the blink reflex and of the exteroceptive suppression of the contracting sternocleidomastoid muscle in blepharospasm and torticollis. Mov Disord 9:183-187. Medline

Christian KM, Thompson RF (2003) Neural substrates of eyeblink conditioning: acquisition and retention. Learn Mem 10:427-455. CrossRef Medline

Cohen LG, Ludlow CL, Warden M, Estegui M, Agostino R, Sedory SE, Holloway E, Dambrosia J, Hallett M (1989) Blink reflex excitability recovery curves in patients with spasmodic dysphonia. Neurology 39:572-577. CrossRef Medline

Colebatch JG, Di Lazzaro V, Quartarone A, Rothwell JC, Gresty M (1995) Click-evoked vestibulocollic reflexes in torticollis. Mov Disord 10:455-459. CrossRef Medline

Cruccu G, Berardelli A, Inghilleri M, Manfredi M (1989) Functional organization of the trigeminal motor system in man. A neurophysiological study. Brain 112:1333-1350. CrossRef Medline

Curra A, Romaniello A, Berardelli A, Cruccu G, ManfrediM (2000) Shortened cortical silent period in facial muscles of patients with cranial dystonia. Neurology 54:130-135. Medline

Cruccu G, Iannetti GD, Marx JJ, Thoemke F, Truini A, Fitzek S, Galeotti F, Urban PP, Romaniello A, Stoeter P, Manfredi M, Hopf HC (2005) Brainstem reflex circuits revisited. Brain 128:386-394. CrossRef Medline

de Entrambasaguas M, Plaza-Costa A, Casal J, Parra S (2007) Labial dystonia after facial and trigeminal neuropathy controlled with a maxillary splint. Mov Disord 22:1355-1358. CrossRef Medline

de Tommaso M, Murasecco D, Libro G, Guido M, Sciruicchio V, Specchio LM, Gallai V, Puca F (2002) Modulation of trigeminal reflex excitability in migraine: effects of attention and ha- bituation on the blink reflex. Int J Psychophysiol 44:239-249. CrossRef Medline

De Vito A, Gastaldo E, Tugnoli V, Eleopra R, Casula A, Tola MR, Granieri E, Quatrale R (2009) Effect of slow rTMS of motor cortex on the excitability of the blink reflex: a study in healthy humans. Clin Neurophysiol 120:174180. CrossRef Medline

Devoize L, Doméjean S, Melin C, Raboisson P, Artola A, Dallel R (2010) Organization of projections from the spinal trigeminal subnucleus oralis to the spinal cord in the rat: a neuroanatomical substrate for reciprocal orofacial-cervical interactions. Brain Res 1343:75-82. CrossRef Medline

Di Lazzaro V, Quartarone A, Higuchi K, Rothwell JC (1995) Short-latency trigemino-cervical reflexes in man. Exp Brain Res 102:474-482. Medline

Di Lazzaro V, Restuccia D, Nardone R, Tartaglione T, Quartarone A, Tonali P, Rothwell JC (1996) Preliminary clinical observations on a new trigeminal reflex: the trigemino-cervical reflex. Neurology 46:479-485. CrossRef Medline

Di Lazzaro V, Guney F, Akpinar Z, Yürüten B, Oliviero A, Pilato F, Saturno E, Dileone M, Tonali PA, Rothwell JC (2006) Trigemino-cervical reflexes: clinical applications and neuroradiological correlations. Suppl Clin Neurophysiol 58:110-119. CrossRef Medline

Edvinsson L (2011) Tracing neural connections to pain pathways with relevance to primary headaches. Cephalalgia 31:737-747. CrossRef Medline

Eekhof JL, Aramideh M, Bour LJ, Hilgevoord AA, Speelman HD, Ongerboer de Visser BW (1996) Blink reflex recovery curves in blepharospasm, torticollis spasmodica, and hemifacial spasm. Muscle Nerve 19:10-15. CrossRef Medline

Ellrich J, Treede RD (1998) Characterization of blink reflex interneurons by activation of diffuse noxious inhibitory controls in man. Brain Res 803:161-168. CrossRef Medline

Ellrich J, Andersen OK, Treede RD, ArendtNielsen L (1998) Convergence of nociceptive and non-nociceptive input onto the medullary dorsal horn in man. Neuroreport 9:3213-3217. CrossRef Medline

Ertekin C, Celebisoy N, Uludağ B (1996) Trigemino-cervical reflexes in normal subjects. J Neurol Sci 143:84-90. CrossRef Medline

Ertekin C, Celebisoy N, Uludağ B (2001) Trigeminocervical reflexes elicited by stimulation of the infraorbital nerve: head retraction reflex. J Clin Neurophysiol 18:378-385. CrossRef Medline

Erzurumlu RS, Killackey HP (1979) Efferent connections of the brainstem trigeminal complex with the facial nucleus of the rat. J Comp Neurol 188:75-86. CrossRef Medline

Fahn S (1984) The varied clinical expressions of dystonia. Neurol Clin 2:541-554. Medline

Foley-Nolan D, Kinirons M, Coughlan RJ, O’Connor P (1990) Post whiplash dystonia well controlled by transcutaneous electrical nervous stimulation (TENS): case report. J Trauma 30:909-910. CrossRef Medline

Ge HY, Wang K, Madeleine P, Svensson P, Sessle BJ, Arendt-Nielsen L (2004) Simultaneous modulation of the exteroceptive suppression periods in the trapezius and temporalis mus- cles by experimental muscle pain. Clin Neurophysiol 115:1399-1408. CrossRef Medline

Gerwig M, Kolb FP, Timmann D (2007) The involvement of the human cerebellum in eyeblink conditioning. Cerebellum 6:38-57. CrossRef Medline

Girlanda P, Quartarone A, Sinicropi S, Nicolosi C, Messina C (1996) Unilateral injection of botulinum toxin in blepharospasm: single fiber electromyography and blink reflex study. Mov Disord 11:27-31. CrossRef Medline

Godaux E, Desmedt JE (1975) Exteroceptive suppression and motor control of the masseter and temporalis muscles in normal man. Brain Res 85:447-458. CrossRef Medline

Gómez-Wong E, Martí MJ, Cossu G, Fabregat N, Tolosa ES, Valls-Solé J (1998) The "geste antagonistique" induces transient modulation of the blink reflex in human patients with blepharospasm. Neurosci Lett 251:125-128. CrossRef Medline

Grandas F, Traba A, Alonso F, Esteban A (1998) Blink reflex recovery cycle in patients with blepharospasm unilaterally treated with botulinum toxin. Clin Neuropharmacol 21:307311. Medline

Guy N, Chalus M, Dallel R, Voisin DL (2005) Both oral and caudal parts of the spinal trigeminal nucleus project to the somatosensory thalamus in the rat. Eur J Neurosci 21:741754. CrossRef Medline

Hallett M (2011) Neurophysiology of dystonia: the role of inhibition. Neurobiol Dis 42:177184. CrossRef Medline

Hoffland BS, Bologna M, Kassavetis P, Teo JT, Rothwell JC, Yeo CH, van de Warrenburg BP, Edwards MJ (2012) Cerebellar theta burst stimulation impairs eyeblink classical conditioning. J Physiol 590:887-897. CrossRef Medline

Hoffland BS, Kassavetis P, Bologna M, Teo JT, Bhatia KP, Rothwell JC, Edwards MJ, van de Warrenburg BP (2013) Cerebellum-dependent associative learning deficits in primary dystonia are normalized by rTMS and practice. Eur J Neurosci 38:2166-2171. CrossRef Medline

Huang YZ, Rothwell JC, Lu CS, Wang J, Chen RS (2010) Restoration of motor inhibition through an abnormal premotor-motor connection in dystonia. Mov Disord 25:696-703. CrossRef Medline

Huang YZ, Lu CS, Rothwell JC, Lo CC, Chuang WL, Weng YH, Lai SC, Chen RS (2012) Modulation of the disturbed motor network in dystonia by multisession suppression of premotor cortex. PLoS One 7:e47574. CrossRef Medline

Huerta MF, Frankfurter A, Harting JK (1983) Studies of the principal sensory and spinal trigeminal nuclei of the rat: projections to the superior colliculus, inferior olive, and cerebellum. J Comp Neurol 220:147-167. CrossRef Medline

Hung SW, Hamani C, Lozano AM, Poon YY, Piboolnurak P, Miyasaki JM, Lang AE, Dostrovsky JO, Hutchison WD, Moro E (2007) Longterm outcome of bilateral pallidal deep brain stimulation for primary cervical dystonia. Neurology 68:457-459. CrossRef Medline

Jeong SG, Lee MK, Kang JY, Jun SM, Lee WH, Ghang CG (2009) Pallidal deep brain stimulation in primary cervical dystonia with phasic type: clinical outcome and postoperative 
course. J Korean Neurosurg Soc 46:346-350. CrossRef Medline

Jinnah HA, Hess EJ (2006) A new twist on the anatomy of dystonia: the basal ganglia and the cerebellum? Neurology 67:1740-1741. CrossRef Medline

Jinnah HA, Berardelli A, Comella C, Defazio G, Delong MR, Factor S, Galpern WR, Hallett M, Ludlow CL, Perlmutter JS, Rosen AR (2013) The focal dystonias: current views and challenges for future research. Mov Disord 28: 926-943. CrossRef Medline

Kawamura S, Hattori S, Higo S, Matsuyama T (1982) The cerebellar projections to the superior colliculus and pretectum in the cat: an autoradiographic and horseradish peroxidase study. Neuroscience 7:1673-1689. CrossRef Medline

Kerr FW (1963) The divisional organization of afferent fibres of the trigeminal nerve. Brain 86:721-732. CrossRef Medline

Kimberley TJ, Borich MR, Arora S, Siebner HR (2013) Multiple sessions of low-frequency repetitive transcranial magnetic stimulation in focal hand dystonia: clinical and physiological effects. Restor Neurol Neurosci 31:533542. CrossRef Medline

Kimura J (1973) Disorder of interneurons in Parkinsonism. The orbicularis oculi reflex to paired stimuli. Brain 96:87-96. CrossRef Medline

Kojovic M, Caronni A, Bologna M, Rothwell JC, Bhatia KP, Edwards MJ (2011) Botulinum toxin injections reduce associative plasticity in patients with primary dystonia. Mov Disord 26:1282-1289. CrossRef Medline

Komiyama O, Wang K, Svensson P, ArendtNielsen L, De Laat A, Kawara M (2010) Magnetic and electric stimulation to elicit the masseteric exteroceptive suppression period. Clin Neurophysiol 121:793-799. CrossRef Medline

Kranz G, Shamim EA, Lin PT, Kranz GS, Hallett M (2013) Long-term depression-like plasticity of the blink reflex for the treatment of blepharospasm. Mov Disord 28:498-503. CrossRef Medline

LiYQ, Takada M, Ohishi H, Shinonaga Y, Mizuno N (1992) Trigeminal ganglion neurons which project by way of axon collaterals to both the caudal spinal trigeminal and the principal sensory trigeminal nuclei. Brain Res 594:155-159. CrossRef Medline

Lim VK (2007) Health related quality of life in patients with dystonia and their caregivers in New Zealand and Australia. Mov Disord 22: 998-1003. CrossRef Medline

Lohmann K, Klein C (2013) Genetics of dystonia: what's known? What's new? What's next? Mov Disord 28:899-905. CrossRef Medline

Luo PF, Li JS (1991) Monosynaptic connections between neurons of trigeminal mesencephalic nucleus and jaw-closing motoneurons in the rat: an intracellular horseradish peroxidase labelling study. Brain Res 559:267-275. CrossRef Medline

Matsushita M, Okado N, Ikeda M, Hosoya Y (1981) Descending projections from the spinal and mesencephalic nuclei of the trigeminal nerve to the spinal cord in the cat. A study with the horseradish peroxidase technique.
J Comp Neurol 196:173-187. CrossRef Medline

Milanov I, Bogdanova D (2003) Trigeminocervical reflex in patients with headache. Cephalalgia 23:35-38. CrossRef Medline

Milanov I, Bogdanova D, Ishpekova B (2001) The trigemino-cervical reflex in normal subjects. Funct Neurol 16:129-134. Medline

Mørch CD, Hu JW, Arendt-Nielsen L, Sessle BJ (2007) Convergence of cutaneous, musculoskeletal, dural and visceral afferents onto nociceptive neurons in the first cervical dorsal horn. Eur J Neurosci 26:142-154. CrossRef Medline

Morcuende S, Delgado-Garcia JM, Ugolini G (2002) Neuronal premotor networks involved in eyelid responses: retrograde transneuronal tracing with rabies virus from the orbicularis oculi muscle in the rat. J Neurosci 22:8808-8818. Medline

Münchau A, Bronstein AM (2001) Role of the vestibular system in the pathophysiology of spasmodic torticollis. J Neurol Neurosurg Psychiatry 71:285-288. CrossRef Medline

Münchau A, Corna S, Gresty MA, Bhatia KP, Palmer JD, Dressler D, Quinn NP, Rothwell JC, Bronstein AM (2001) Abnormal interaction between vestibular and voluntary head control in patients with spasmodic torticollis. Brain 124:47-59. CrossRef Medline

Murase N, Rothwell JC, Kaji R, Urushihara R, Nakamura K, Murayama N, Igasaki T, SakataIgasaki M, Mima T, Ikeda A, Shibasaki $\mathrm{H}$ (2005) Subthreshold low-frequency repetitive transcranial magnetic stimulation over the premotor cortex modulates writer's cramp. Brain 128:104-115. CrossRef Medline

Nakashima K, Takahashi K (1991) Exteroceptive suppression of the masseter, temporalis and trapezius muscles produced by mental nerve stimulation in patients with chronic headaches. Cephalalgia 11:23-28. CrossRef Medline

Nakashima K, Thompson PD, Rothwell JC, Day BL, Stell R, Marsden CD (1989) An exteroceptive reflex in the sternocleidomastoid muscle produced by electrical stimulation of the supraorbital nerve in normal subjects and patients with spasmodic torticollis. Neurology 39:1354-1358. CrossRef Medline

Nakashima K, Takahashi K, Azumi T, Ishida G (1990) Exteroceptive suppression of the masseter and temporalis muscles produced by electrical stimulation of the mental nerve in patients with Parkinson's disease. Acta Neurol Scand 81:407-410. Medline

Nakashima K, Takahashi K, Azumi T, Ishida G (1992) Exteroceptive suppression of the trapezius muscle produced by mental nerve stimulation in normal subjects. Electromyogr Clin Neurophysiol 32:471-475. Medline

Nardone R, Tezzon F (2003a) The trigeminocervical reflex in tension-type headache. Eur J Neurol 10:307-312. CrossRef Medline

Nardone R, Tezzon F (2003b) Short latency trigemino-sternocleidomastoid response in patients with migraine. J Neurol 250:725-732. CrossRef Medline

Nardone R, Ausserer H, Bratti A, Covi M, Lochner P, Marth R, Florio I, Tezzon F (2008) Trigemino-cervical reflex abnormalities in patients with migraine and cluster headache. Headache 48:578-585. CrossRef Medline

Neychev VK, Fan X, Mitev VI, Hess EJ, Jinnah HA (2008) The basal ganglia and cerebellum interact in the expression of dystonic movement. Brain 131:2499-2509. CrossRef Medline

Neychev VK, Gross RE, Lehéricy S, Hess EJ, Jinnah HA (2011) The functional neuroanatomy of dystonia. Neurobiol Dis 42:185-201. CrossRef Medline

Nordstrom MA (2007) Insights into the bilateral cortical control of human masticatory muscles revealed by transcranial magnetic stimulation. Arch Oral Biol 52:338-342. CrossRef Medline

Odergren T, Rimpilainen I, Borg J (1997) Sternocleidomastoid muscle responses to transcranial magnetic stimulation in patients with cervical dystonia. Electroencephalogr Clin Neurophysiol 105:44-52. Medline

Panneton WM, Gan Q, Livergood RS (2011) A trigeminoreticular pathway: implications in pain. PLoS One 6:e24499. CrossRef Medline

Pauletti G, Berardelli A, Cruccu G, Agostino R, Manfredi M (1993) Blink reflex and the masseter inhibitory reflex in patients with dystonia. Mov Disord 8:495-500. CrossRef Medline

Pekmezovic T, Svetel M, Ivanovic N, Dragasevic N, Petrovic I, Tepavcevic DK, Kostic VS (2009) Quality of life in patients with focal dystonia. Clin Neurol Neurosurg 111:161164. CrossRef Medline

Pellegrini JJ, Evinger C (1995) The trigeminally evoked blink reflex. II. Mechanisms of pairedstimulus suppression. Exp Brain Res 107:181196. CrossRef Medline

Pellegrini JJ, Evinger C (1997) Role of cerebellum in adaptive modification of reflex blinks. Learn Mem 4:77-87. CrossRef Medline

Pelosin E, Avanzino L, Marchese R, Stramesi P, Bilanci M, Trompetto C, Abbruzzese G (2013) KinesioTaping reduces pain and modulates sensory function in patients with focal dystonia: a randomized crossover pilot study. Neurorehabil Neural Repair 27:722731. CrossRef Medline

Penders CA, Delwaide PJ (1971) Blink reflex studies in patients with Parkinsonism before and during therapy. J Neurol Neurosurg Psychiatry 34:674-678. CrossRef Medline

Peterson DA, Sejnowski TJ, Poizner H (2010) Convergent evidence for abnormal striatal synaptic plasticity in dystonia. Neurobiol Dis 37:558-573. CrossRef Medline

Phukan J, Albanese A, Gasser T, Warner T (2011) Primary dystonia and dystonia-plus syndromes: clinical characteristics, diagnosis, and pathogenesis. Lancet Neurol 10:1074-1085. CrossRef Medline

Proietti Cecchini A, Sandrini G, Fokin IV, Moglia A, Nappi G (2003) Trigeminofacial reflexes in primary headaches. Cephalalgia 23 [Suppl 1]: 33-41.

Prudente CN, Pardo CA, Xiao J, Hanfelt J, Hess EJ, Ledoux MS, Jinnah HA (2013) Neuropathology of cervical dystonia. Exp Neurol 241: 95-104. CrossRef Medline

Quartarone A, Rizzo V, Bagnato S, Morgante F, Sant'Angelo A, Romano M, Crupi D, Girlanda P, Rothwell JC, Siebner HR (2005) Homeostatic-like plasticity of the primary motor hand 
area is impaired in focal hand dystonia. Brain 128:1943-1950. CrossRef Medline

Quartarone A, Sant'Angelo A, Battaglia F, Bagnato S, Rizzo V, Morgante F, Rothwell JC, Siebner HR, Girlanda P (2006) Enhanced long-term potentiation-like plasticity of the trigeminal blink reflex circuit in blepharospasm. J Neurosci 26:716-721. CrossRef Medline

Quartarone A, Morgante F, Sant'angelo A, Rizzo V, Bagnato S, Terranova C, Siebner HR, Berardelli A, Girlanda P (2008) Abnormal plasticity of sensorimotor circuits extends beyond the affected body part in focal dystonia. J Neurol Neurosurg Psychiatry 79:985-990. CrossRef Medline

Quartarone A, Classen J, Morgante F, Rosenkranz K, Hallett M (2009) Consensus paper: use of transcranial magnetic stimulation to probe motor cortex plasticity in dystonia and levodopa-induced dyskinesia. Brain Stimul 2:108-117. CrossRef Medline

Raike RS, Pizoli CE, Weisz C, van den Maagdenberg AM, Jinnah HA, Hess EJ (2012) Limited regional cerebellar dysfunction induces focal dystonia in mice. Neurobiol Dis 49C: 200-210. CrossRef Medline

Ro JY, Capra NF (1994) Receptive field properties of trigeminothalamic neurons in the rostral trigeminal sensory nuclei of cats. Somatosens Mot Res 11:119-130. CrossRef Medline

Romaniello A, Svensson P, Cruccu G, ArendtNielsen L (2000) Modulation of exteroceptive suppression periods in human jaw-closing muscles induced by summation of nociceptive and non-nociceptive inputs. Exp Brain Res 132:306313. CrossRef Medline

Romaniello A, Iannetti GD, Truini A, Cruccu G (2003) Trigeminal responses to laser stimuli. Neurophysiol Clin 33:315-324. CrossRef Medline

Rosengren SM, Colebatch JG (2010) Vestibular evoked myogenic potentials are intact in cervical dystonia. Mov Disord 25:2845-2853. CrossRef Medline

Sadnicka A, Hoffland BS, Bhatia KP, van de Warrenburg BP, Edwards MJ (2012) The cerebellum in dystonia-help or hindrance? Clin Neurophysiol 123:65-70. CrossRef Medline

Sadnicka A, Kimmich O, Pisarek C, Ruge D, Galea J, Kassavetis P, Parees I, Saifee T, Molloy A, Bradley D, O'Riordan S, Zrinzo L, Hariz M, Bhatia KP, Limousin P, Foltynie T, Rothwell JC, Hutchinson M, Edwards MJ (2013) Pallidal stimulation for cervical dystonia does not correct abnormal temporal discrimination. Mov Disord. Advance online publication. Retrieved October 17, 2013. doi:10.1002/ mds.25581. CrossRef Medline

Schicatano EJ, Mantzouranis J, Peshori KR, Partin J, Evinger C (2002) Lid restraint evokes two types of motor adaptation. J Neurosci 22:569576. Medline

Schoenen J, Jamart B, Gerard P, Lenarduzzi P, Delwaide PJ (1987) Exteroceptive suppression of temporalis muscle activity in chronic headache. Neurology 37:1834-1836. CrossRef Medline

Schwingenschuh P, Katschnig P, Edwards MJ, Teo JT, Korlipara LV, Rothwell JC, Bhatia KP (2011) The blink reflex recovery cycle differs between essential and presumed psycho- genic blepharospasm. Neurology 76:610614. CrossRef Medline

Serrao M, Rossi P, Parisi L, Perrotta A, Bartolo M, Cardinali P, Amabile G, Pierelli F (2003) Trigemino-cervical-spinal reflexes in humans. Clin Neurophysiol 114:1697-1703. CrossRef Medline

Sessle BJ (2000) Acute and chronic craniofacial pain: brainstem mechanisms of nociceptive transmission and neuroplasticity, and their clinical correlates. Crit Rev Oral Biol Med 11: 57-91. CrossRef Medline

Sessle BJ (2002) Recent insights into brainstem mechanisms underlying craniofacial pain. J Dent Educ 66:108-112. Medline

Sessle BJ, Hu JW, Amano N, Zhong G (1986) Convergence of cutaneous, tooth pulp, visceral, neck and muscle afferents onto nociceptive and non-nociceptive neurones in trigeminal subnucleus caudalis (medullary dorsal horn) and its implications for referred pain. Pain 27:219-235. CrossRef Medline

Siebner HR, Tormos JM, Ceballos-Baumann AO, Auer C, Catala MD, Conrad B, Pascual-Leone A (1999) Low-frequency repetitive transcranial magnetic stimulation of the motor cortex in writer's cramp. Neurology 52:529-537. CrossRef Medline

Sims AB, Stack BC, Demerjian GG (2012) Spasmodic torticollis: the dental connection. Cranio 30:188-193. Medline

Slawek J, Friedman A, Potulska A, Krystkowiak P, Gervais C, Banach M, Ochudlo S, Budrewicz S, Reclawowicz D, Rynkowski M, Opala G (2007) Factors affecting the health-related quality of life of patients with cervical dystonia and the impact of botulinum toxin type $\mathrm{A}$ injections. Funct Neurol 22:95-100. Medline

Smith RL (1975) Axonal projections and connections of the principal sensory trigeminal nucleus in the monkey. J Comp Neurol 163: 347-375. CrossRef Medline

Snaith A, Wade D (2011) Dystonia. Clin Evid (Online) pii:1211. Medline

Somana R, Kotchabhakdi N, Walberg F (1980) Cerebellar afferents from the trigeminal sensory nuclei in the cat. Exp Brain Res 38:57-64. Medline

Song CH, Bernhard D, Bolarinwa C, Hess EJ, Smith Y, Jinnah HA (2013) Subtle microstructural changes of the striatum in a DYT1 knock-in mouse model of dystonia. Neurobiol Dis 54:362-371. CrossRef Medline

Steeves TD, Day L, Dykeman J, Jette N, Pringsheim T (2012) The prevalence of primary dystonia: a systematic review and meta-analysis. Mov Disord 27: 1789-1796. CrossRef Medline

Szentagothai J (1948) Anatomical considerations on monosynaptic reflex arcs. J Neurophysiol 11:445-454. Medline

Takeda M, Takahashi M, Matsumoto S (2012) Suppression of neurokinin-1 receptor in trigeminal ganglia attenuates central sensitization following inflammation. J Peripher Nerv Syst 17:169-181. CrossRef Medline

Tassorelli C, Mancini F, Balloni L, Pacchetti C, Sandrini G, Nappi G, Martignoni E (2006) Botulinum toxin and neuromotor rehabilitation: an integrated approach to idiopathic cervical dystonia. Mov Disord 21:2240-2243. CrossRef Medline

Teo JT, van de Warrenburg BP, Schneider SA,
Rothwell JC, Bhatia KP (2009) Neurophysiological evidence for cerebellar dysfunction in primary focal dystonia. J Neurol Neurosurg Psychiatry 80:80-83. CrossRef Medline

Thickbroom GW, Byrnes ML, Stell R, Mastaglia FL (2003) Reversible reorganisation of the motor cortical representation of the hand in cervical dystonia. Mov Disord 18:395-402. CrossRef Medline

Tinazzi M, Farina S, Bhatia K, Fiaschi A, Moretto G, Bertolasi L, Zarattini S, Smania N (2005) TENS for the treatment of writer's cramp dystonia: a randomized, placebo-controlled study. Neurology 64: 1946-1948. CrossRef Medline

Todorov B, Kros L, Shyti R, Plak P, Haasdijk ED, Raike RS, Frants RR, Hess EJ, Hoebeek FE, De Zeeuw CI, van den Maagdenberg AM (2012) Purkinje cell-specific ablation of Cav2.1 channels is sufficient to cause cerebellar ataxia in mice. Cerebellum 11:246-258. CrossRef Medline

Toglia JU, Izzo K (1985) Treatment of myoclonic dystonia with transcutaneous electrical nerve stimulation. Ital J Neurol Sci 6:75-78. CrossRef Medline

Tolosa E, Montserrat L, Bayes A (1988a) Blink reflex studies in focal dystonias: enhanced excitability of brainstem interneurons in cranial dystonia and spasmodic torticollis. Mov Disord 3:61-69. CrossRef Medline

Tolosa E, Montserrat L, Bayes A (1988b) Blink reflex studies in patients with focal dystonias. Adv Neurol 50:517-524. Medline

Valls-Sole J (2012) Assessment of excitability in brainstem circuits mediating the blink reflex and the startle reaction. Clin Neurophysiol 123:13-20. CrossRef Medline

Wang K, Svensson P, Arendt-Nielsen L (1999) Modulation of exteroceptive suppression periods in human jaw-closing muscles by local and remote experimental muscle pain. Pain 82:253-262. CrossRef Medline

Wang N, May PJ (2008) Peripheral muscle targets and central projections of the mesencephalic trigeminal nucleus in macaque monkeys. Anat Rec (Hoboken) 291:974-987. CrossRef Medline

Witt JL, Moro E, Ash RS, Hamani C, Starr PA, Lozano AM, Hodaie M, Poon YY, Markun LC, Ostrem JL (2013) Predictive factors of outcome in primary cervical dystonia following pallidal deep brain stimulation. Mov Disord 28:1451-1455. CrossRef Medline

Xue HG, Yang CY, Yamamoto N (2008) Afferent sources to the inferior olive and distribution of the olivocerebellar climbing fibers in cyprinids. J Comp Neurol 507:1409-1427. CrossRef Medline

Zetterberg L, Halvorsen K, Färnstrand C, Aquilonius SM, Lindmark B (2008) Physiotherapy in cervical dystonia: six experimental singlecase studies. Physiother Theory Pract 24:275290. CrossRef Medline

Zetterberg L, Aquilonius SM, Lindmark B (2009) Impact of dystonia on quality of life and health in a Swedish population. Acta Neurol Scand 119:376-382. CrossRef Medline

Zurowski M, McDonald WM, Fox S, Marsh L (2013) Psychiatric comorbidities in dystonia: emerging concepts. Mov Disord 28:914-920. CrossRef Medline 